Marketing in Asia Group

\title{
Exploring Synergetic Effects of Social-Media Communication and Distribution Strategy on Consumer- Based Brand Equity
}

\author{
Man Lai Cheung \\ Department of Marketing, The Hang Seng University of Hong Hong, Hong Kong \\ Newcastle Business School, University of Newcastle, Australia
}

Guilherme D. Pires

Newcastle Business School, University of Newcastle, Australia

Philip J. Rosenberger III

Central Coast Business School, University of Newcastle - Central Coast, Australia

\begin{abstract}
This study examines the effectiveness of social-media brand communication and intensive-distribution strategy on the consumer-based brand equity dimensions, also accounting for the moderating effect of product involvement. The theoretical framework is tested using data collected from 210 consumers who shopped in electronic-appliance stores (high involvement) or sports-apparel stores (low involvement) in a shopping mall in Hong Kong. Data analysis used partial least squares - structural equation modelling (PLS-SEM). The results show that firmcreated social-media brand communication and distribution intensity are key factors influencing consumer-based brand equity, with the moderating effect of product involvement also confirmed. However, inconsistent with previous studies, there is only partial support for the impact of user-generated social-media brand communication on consumer-based brand equity dimensions for both high- and lowinvolvement products. This study enables managers and academics to better understand the combined effectiveness of social media marketing and distribution intensity, as well as the moderating effect of product-involvement level for better resource allocation.
\end{abstract}

Keywords: Social Media, Online and Offline Marketing, Distribution Intensity, Brand Equity, Product Involvement

Publication Details: Received 18 Mar 2019; Revised 27 Mar 2020; Accepted 15 Apr 2020 


\section{Introduction}

Brands can help consumers interpret and process information by adding meaning and feelings to the product, providing them with confidence in their purchase-decisionmaking process (Aaker, 2001). Accordingly, brand building is widely acknowledged as an important area for marketing research (Keller, 2012), and consumer-based brand equity (CBBE) is deemed the most valuable outcome of brand-building activities (Cheung et al., 2018). By creating product differentiation and enhancing market capitalization, CBBE refers to the incremental value added to a product by its brand (Yoo \& Donthu, 2002) and is recognised for its importance as a source of competitive advantage and business success (Cheung et al., 2019a).

Research investigates the antecedents of CBBE, including the use of traditional advertisements, web advertising and social media marketing (Cheung et al., 2019b). For example, the literature highlights the importance of creating multiple touchpoints by integrating social-media communication with distribution-channel intensity in the brand-building process (Ataman et al., 2008; Herausen et al., 2015) to create repeated exposure for brands, hence building strong and positive brand knowledge (Kumar et al., 2017). However, knowledge about the antecedents of CBBE remains fragmented, and intelligence on the relative importance of social media brand communication and distribution intensity is lacking.

The advent of digital marketing promoted social-media brand communication to be one of the most important sources of CBBE (Schivinski \& Dabrowski, 2016). Using social media as a communication platform allows marketers to create and exchange information about brands with consumers, facilitating the creation of CBBE by building strong and positive brand knowledge in consumers' minds (Kim \& Ko, 2012). Since social media is increasingly substituting for traditional media in its influence on brand building (Morra et al., 2017), prominent scholarly focus is on consumer-brand interactions, user-generated content, and social-media brand communication in social-media contexts (Schivinski \& Dabrowski, 2016).

Notwithstanding, the effect of social-media brand communication on CBBE is not well understood, particularly in combination with offline marketing activities, such as intensive-distribution strategy (Cheung et al., 2019b). Some studies suggest marketers should increase the number of showrooms and physical stores to build brand image (Bell et al., 2017; Cao \& Li, 2015; Pauwels \& Neslin, 2015), whilst others suggest putting more effort into social-media activities (Malthouse et al., 2016; Valos et al., 2017). Thus, firms increasingly integrate social-media marketing with intensivedistribution channels to deliver product information, interact with consumers, and create positive brand experiences in consumers' minds (Bell et al., 2017; Herhausen et al., 2015; Sun et al., 2015). 
Whilst the literature explores how distribution-channel intensity can be used to build CBBE (e.g. Nguyen et al., 2011; Yoo et al., 2000), little is known about the integrated effects of using both social media communication and distribution channel intensity on CBBE for both high- and low-involvement products (Kumar et al., 2017; Srinivasan et al., 2015). This justifies the need for research of effective brand-building processes that examine how social-media brand communication influences CBBE and distribution channel intensity effects. There is also a need to understand how this influence may vary based on the level of product involvement, a matter recognised as a key research priority by the Marketing Science Institute (MSI, 2018). The following critical research questions express these two research areas:

1) What is the role of social media communication and distribution channel intensity in the brand-building process?

2) How does social media communication and distribution intensity influence CBBE across products with different (i.e. high and low) involvement levels?

This research examines the effectiveness of using social-media communication and distribution strategy in building CBBE, and how this can vary based on the level of product involvement. Beyond enhancing theoretical understanding, the present research assists in recognising the synergistic benefits of combining social-media communication and distribution strategy to generate higher CBBE from the consumer's perspective, for brands in both high- and low-involvement product categories, thus facilitating actions to foster the combined use of these elements.

\section{Theoretical Background and Hypotheses}

\section{Consumer Based Brand Equity (CBBE)}

Showing how a brand's success is directly attributable to consumers' attitudes towards that brand, $\mathrm{CBBE}$ is a multidimensional concept consisting of the set of brand assets/liabilities that resonate with consumers, providing favourable/unfavourable effects on the value of the brand (Cheung et al., 2019b). It encompasses brand awareness, brand associations, perceived quality and brand loyalty (Schivinski \& Dabrowski, 2015). Brand awareness refers to potential consumers' ability to recognise/recall a brand in their minds (Aaker, 1991), making it more likely to be considered at the point of purchase (Keller, 1993). Brand association refers to positive or negative attributes linked to consumers' memory of a brand (Aaker, 1991) supportive experiences and communications arguably create strong and favourable associations with the brand (Cheung et al., 2019b). Perceived quality refers to consumers' subjective evaluation of overall brand quality (Schivinski \& Dabrowski, 2015), prone to strengthening through quality signals conveyed by different forms of marketing communication or experience (Yoo et al., 2000). Finally, at the heart of CBBE (Keller, 2016), brand loyalty refers to consumers' attachment to a brand, 
demonstrated by their ongoing purchase of the brand as their primary choice (Keller, 2009). Overall, the CBBE dimensions strengthen purchase intentions (Cobb-Walgren et al., 1995), enhance customer lifetime value (Lee et al., 2014), and deliver additional financial value to firms (De Olivia et al., 2015).

Reflecting the importance afforded to CBBE, there is growing scholarly interest in examining the antecedents of the CBBE dimensions (Davcik et al., 2015), although the integrated effect of social-media communication and distribution strategy in the brand-building process still needs investigation. Table 1 presents a summary of the $\mathrm{CBBE}$ literature with key findings related to the importance of social-media communication and distribution-channel efforts.

Table 1: Summary of Key Findings from CBBE Literature

\begin{tabular}{|c|c|c|c|}
\hline Source & Focal product & Sample/ Data & Key findings \\
\hline $\begin{array}{l}\text { Bruhn et al. } \\
(2012)\end{array}$ & $\begin{array}{l}\text { Tourism, } \\
\text { telecommunications, } \\
\text { and pharmaceuticals }\end{array}$ & $\begin{array}{l}393 \text { consumers in } \\
\text { German-speaking } \\
\text { countries }\end{array}$ & $\begin{array}{l}\text { Both social media communication and traditional } \\
\text { advertising are useful in driving CBBE. While } \\
\text { Traditional advertising has a stronger impact on } \\
\text { brand awareness, FCSM plays a considerable role } \\
\text { in driving brand image. }\end{array}$ \\
\hline $\begin{array}{l}\text { Schivinski \& } \\
\text { Dabrowski } \\
(2015)\end{array}$ & $\begin{array}{l}\text { Non-alcoholic } \\
\text { beverages, clothing, } \\
\text { and mobile network }\end{array}$ & $\begin{array}{l}302 \text { consumers in } \\
\text { Poland }\end{array}$ & $\begin{array}{l}\text { FCSM strengthens brand awareness only; UGSM } \\
\text { has significant impact on the four CBBE } \\
\text { dimensions. }\end{array}$ \\
\hline $\begin{array}{l}\text { Godey et al. } \\
(2016)\end{array}$ & Luxury fashion & $\begin{array}{l}845 \text { consumers in } \\
\text { China, France, } \\
\text { India and Italy }\end{array}$ & $\begin{array}{l}\text { Firm-initiated, social-media marketing activities is } \\
\text { positively related to CBBE of luxury fashion, a } \\
\text { high-involvement product. }\end{array}$ \\
\hline $\begin{array}{l}\text { Kim \& Ko } \\
(2012)\end{array}$ & Luxury fashion & $\begin{array}{l}362 \text { luxury } \\
\text { consumers in } \\
\text { Korea }\end{array}$ & $\begin{array}{l}\text { Firm-initiated, social-media marketing activities is } \\
\text { positively related to CBBE of luxury fashion, a } \\
\text { high-involvement product. }\end{array}$ \\
\hline $\begin{array}{l}\text { Kumar et al. } \\
(2017)\end{array}$ & Ice-cream & $\begin{array}{l}\text { Sales of US ice- } \\
\text { cream brands }\end{array}$ & $\begin{array}{l}\text { In-store promotion and social-media } \\
\text { communication are critical drivers in boosting } \\
\text { brand sales. }\end{array}$ \\
\hline $\begin{array}{l}\text { Morra et al., } \\
(2017)\end{array}$ & Beer & $\begin{array}{l}183 \text { consumers in } \\
\text { Italy }\end{array}$ & $\begin{array}{l}\text { FCSM strengthens brand awareness; UGSM } \\
\text { impacts perceived quality and brand loyalty. } \\
\text { Traditional advertising is not a driver of CBBE. }\end{array}$ \\
\hline $\begin{array}{l}\text { Seo \& Park } \\
(2018)\end{array}$ & Airline & $\begin{array}{l}302 \text { consumers in } \\
\text { Korea }\end{array}$ & $\begin{array}{l}\text { Firm-initiated, social-media marketing activities } \\
\text { relate positively to airline CBBE, a high- } \\
\text { involvement product. }\end{array}$ \\
\hline
\end{tabular}

Note: FCSM = Firm-created social media brand communication; UGSM = User-generated social media brand communication; $\mathrm{CBBE}=$ Consumer-based brand equity

Most studies focus on the importance of social media marketing communication on CBBE (e.g. Cheung et al., 2020a; Godey et al., 2016; Seo \& Park, 2018). Several others examine the integrated effect of traditional advertising and social-media marketing communications on CBBE and compare their relative importance, concluding that social-media marketing communication plays a considerable role in driving CBBE (Morra et al., 2017). In contrast, Kumar et al. (2017) is one of first study to examine the integrated effect of social-media marketing communication and distribution channel efforts in the CBBE-building process. 
Table 1 also shows that the literature does not account for product category differences in the CBBE building process. Thus, the need for research on the integration of social media-marketing communication and distribution-channel intensity on the $\mathrm{CBBE}$ dimensions across products from different categories, namely high and low involvement, as discussed in the following sections.

\section{Integrating Social Media Communication and Distribution Channel Intensity to Drive CBBE}

Proponents of the importance of integrating online and offline marketing efforts in brand building has been identified (Cheung et al., 2019b), recommending a need for marketers to offer a seamless consumer experience across marketing activities, online and offline (Keller, 2013).

Evolving from integrated marketing communications, the integration of online and offline marketing efforts - such as the integration of web advertising, mobile advertising, social-media communication and in-store promotions and distribution convenience - is deemed to increase customer satisfaction, thereby building strong and positive brand knowledge (Kumar et al., 2016). For example, coordinating and integrating social-media marketing communication and distribution-channel efforts can provide synergies to enhance the overall effectiveness of marketing activities in the brand-building process (Ataman et al., 2010; Kumar et al., 2016). Effectiveness results because social-media communication is useful in the brand-building process (Cheung et al., 2020b), and because distribution-channel intensity offers convenience for consumers in searching for branded products (Herhausen et al., 2015). These grounds call for further empirical research examining the integration of socialmarketing communication and distribution channel intensity in the brand-building process (Cheung et al., 2019b), as discussed in the following sections.

\section{Social Media Brand Communication and Consumer-Based Brand Equity Dimensions}

Social media is widely acknowledged as an effective online medium in reaching and influencing consumers' brand knowledge (Cheung et al., 2020b), adding to the value of those brands for marketers either as a price premium or as enhanced brand loyalty (Aaker, 2001). Thus, marketers seek to understand how to use social media to communicate brand information as part of the brand-building process. This involves distinguishing between firm-created, social-media brand communications (FCSM) and user-generated, social-media brand communications (UGSM), hence outside marketers' control (Schivinski \& Dabrowski, 2016).

Similar to web advertising, FCSM involves brand-initiated communication with consumers (Bruhn et al., 2012). Numerous global brands - such as Apple, Dell, Nike and Adidas-use FCSM to provide formal information to consumers about their product's attributes and pricing (Cheung et al., 2019a) through various platforms, such as blogs, Facebook and YouTube. When more FCSM is available, it is easier to 
expose consumers to the firm's communications and to the brand, resulting in the creation, modification and/or reinforcement of brand awareness and brand associations (Schivinski \& Dabrowski, 2015). Indeed, consumers generally perceive brands with more available marketing communications as being higher quality brands (Mangold \& Faulds, 2009), justifying the argument that brand-communication efforts may have a significant positive impact on consumers' satisfaction with the brand and perceived brand quality (Cheung et al., 2020b).

FCSM is also expected to have a positive effect on consumers' perceptions and attitude toward brands, making them more likely to select the brand with more intensive FCSM as their primary choice, thus leading to stronger brand loyalty and purchase intentions (Morra et al., 2017). This supports a positive relationship between the intensity of positive FCSM messages and brand knowledge (Liu et al., 2019). In other words, positive FCSM messages play a role in shaping consumers' positive attitude, thereby building CBBE (Seo \& Park, 2018), providing the rationale underpinning hypotheses 1 a to $1 \mathrm{~d}$, articulated as follows:

H1 FCSM has a positive effect on (a) brand awareness, (b) brand associations, (c) perceived quality and (d) brand loyalty.

Reflecting user-generated (i.e. consumer) publicly available content created outside marketers' control, UGSM includes product reviews, comments and ratings for products and services offered by brands (Schivinski \& Dabrowski, 2016). Compared to FCSM, UGSM content comes from consumers or independent opinion leaders who are not sponsored by business, thus supporting interactions between consumers in an online brand community (Morra et al., 2017) that are perceived as authentic. Similar to electronic word-of-mouth, authenticity results from the perception that UGSM is more trustworthy than FCSM, because it consists of positive or negative informal communication freely and independently generated by consumers about products and brands (Cheung et al., 2018). Compared to traditional communication channels, UGSM based interactions strengthen consumers' positive perceptions towards the brand through gathering brand advocates' ideas and views to improve product design, service level and communication effectiveness, enhancing the competitive power of the brand (Schivinski \& Dabrowski, 2016).

Empirical research also suggests that favourable UGSM has a direct effect on consumers' brand perceptions (Schivinski \& Dabrowski, 2016). Reportedly, UGSM related to a brand creates social interaction and engagement amongst consumers, encouraging consumers' brand recall and strengthening brand awareness (Cheung et al., 2018). That is, UGSM generates multiple experiences, facts, episodes and exposure to brand information, which increase the probability that a brand will be included in consumers' memory and consideration set, thus strengthening consumers' brand associations (Schivinski \& Dabrowski, 2015). UGSM also provides credible product-quality information to consumers that results in a positive effect on their perceived brand quality, and has a positive impact on functional, experimental and symbolic brand benefits, hence leveraging brand loyalty (Bruhn et al., 2012). 
Overall, the literature supports a positive relationship between favourable UGSM and consumers' brand perception, justifying the focus on encouraging consumers to create positive UGSM to drive brand awareness, brand image, satisfaction and attitudinal loyalty (Schivinski \& Dabrowski, 2015), supporting the following hypothesis:

H2 UGSM has a positive effect on (a) brand awareness, (b) brand associations, (c) perceived quality and (d) brand loyalty.

A growing understanding of the importance of social-media brand communication in driving CBBE supports the need to integrate social-media brand communication with intensive distribution in order to enhance the synergistic effects of the marketing efforts. Research on this integration is still in its infancy, justifying the examination below of the relationship between distribution intensity and the CBBE dimensions.

\section{Distribution Intensity}

Brand-controllable marketing efforts, such as advertising, price premiums, store image and distribution intensity, can assist in building brand awareness, along with strong and favourable brand associations, higher perceived quality and brand loyalty (Nguyen et al., 2011). Distribution intensity is an offline marketing effort that represents the width and depth of the distribution of the products offered by a business (Yoo et al., 2000). Firms can promote their products and communicate brand-related information in retail outlets (e.g. using product displays, sampling promotions and providing information about product attributes). These promotion and communication efforts are more intensive when there are more physical stores, showrooms or online distribution outlets, contributing to building positive brand experiences in consumers' minds (Keller, 2013). The focus of distribution intensity is on the degree of effectiveness in generating consumers' awareness of the product/brand, stimulating arousal and trial, seen as a stepping-stone towards strengthening consumers' brand knowledge and satisfaction (Yoo et al., 2000).

The literature suggests that distribution intensity has a direct impact on consumers' awareness of products/brands, such that the more these are available, the easier is for consumers to access, trial and personally experience them (Huang \& Sarigöllü, 2012). This improves consumers' ability to recall and recognise the brand, hence strengthening brand awareness and brand association (Yoo et al., 2000). Accordingly, consumers are likely to be more satisfied when a brand is available in more retail outlets, providing greater purchasing convenience, and thus creating a higher perceived value and quality for the brand in consumers' minds (Yoo \& Donthu, 2002). In summary, consumers often perceive the more available brand as of higher value and as a primary choice in their decision-making process, which enhances brand loyalty, leading to hypotheses 3 a to $3 \mathrm{~d}$ :

H3 Distribution intensity has a positive effect on (a) brand awareness, (b) brand associations, (c) perceived quality and (d) brand loyalty. 


\section{Product Involvement Level as A Moderator}

Variably conceptualised and measured, product/brand involvement refers to the extent of consumers' interest and effort put in its purchasing (Coulter et al., 2003). Involvement with a product/brand reflects its perceived relevance to consumers' inherent needs, values and interests (Cheung et al., 2019a). At high levels of involvement, consumers view the product/brand as central to their life, being meaningful, engaging and important to them (O'Cass, 2000). For this study, enduring involvement refers to a consumer's general, long-run concern towards a product that is independent of a specific situation or circumstance (Cheung et al., 2019a).

Products/brands can be categorised as high-involvement - evaluated based on quality perceptions - or low-involvement, more easily influenced by affection (Zaichkowsky, 1986). The suggestion is that consumers exert greater effort to process relevant information for high-involvement than for low-involvement products/brands, including when considering advertising messages and information available on the Internet (Park et al., 2007). For low-involvement products/brands, consumers lack the motivation to search for and evaluate brand information and are more likely to build brand perceptions based on their emotional experience (Cheung et al., 2019a).

Examined as a moderator in marketing contexts, consideration of productinvolvement level in the CBBE-building process is inconclusive, justifying further clarification (Moradi \& Zarei, 2012). The argument is that FCSM is effective in building consumers' positive brand attitude when considering high-involvement products, since consumers are more willing to search for information using the Internet and firm-initiated social-media brand pages (Cheung et al., 2019a).

In the case of UGSM, the impact of UGSM on brand knowledge for high-involvement products/brands is higher than for low-involvement products/brands. This is because consumers are more willing to search for information via social media when considering high-involvement products/brands, such as luxury, smartphones and airlines (Kim and Ko, 2012; Seo \& Park, 2018). In the opposite, consumers are less willing to do so when considering low-involvement products/brands, such as FMCG available at supermarket and grocery, because they are more willing to make decisions based on convenience (Lin \& Chang, 2003).

In contrast, distribution intensity is more important in building positive brand knowledge for low-involvement products/brands, because it offers greater access and convenience to consumers, hence contributing to building satisfaction and positive brand perceptions (Lin \& Chang, 2003). However, intensive distribution is less relevant for high-involvement products/brands, such as luxury products, cars or laptops, as consumers are willing to expend more effort in searching for the information they need, justifying the use of selective distribution strategies (Cheung et al., 2019b). 
In sum, the argument is that the effects of the CBBE antecedents in the model used in this research (figure 1 below) - namely, FCSM, UGSM and distribution intensity will vary based on product-involvement level, as per the following hypotheses:

H4 The higher the level of product involvement, then the greater the influence of FCSM on (a) brand awareness, (b) brand associations, (c) perceived quality and (d) brand loyalty.

H5 The higher the level of product involvement, then the greater the influence of UGSM on (a) brand awareness, (b) brand associations, (c) perceived quality and (d) brand loyalty.

H6 The lower the level of product involvement, then the greater the influence of distribution intensity on (a) brand awareness (b) brand associations (c) perceived quality and (d) brand loyalty.

Figure 1: Conceptual model

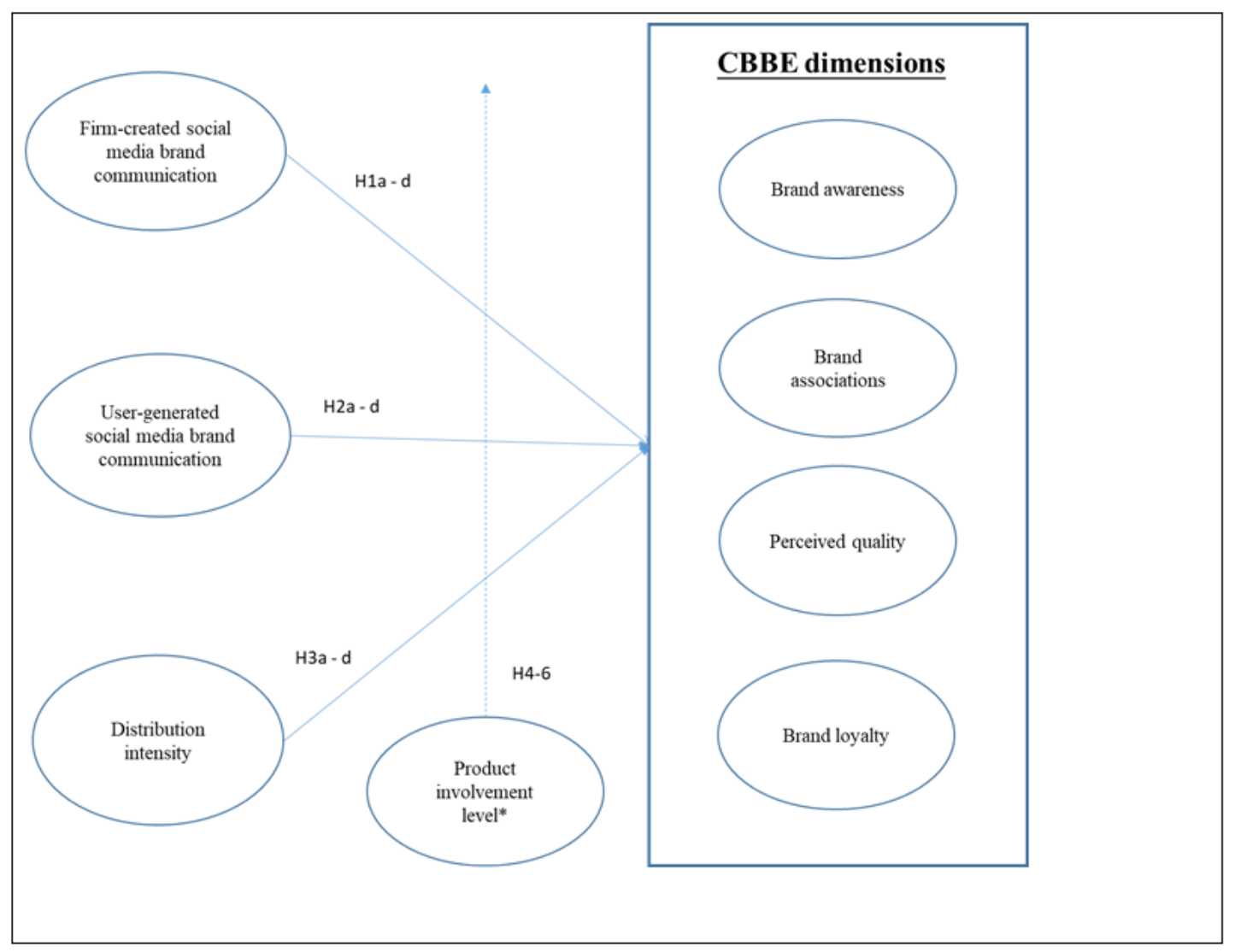

Note: $*=$ moderator 


\section{Methodology}

\section{Data Collection}

Data to evaluate the hypothesised relationships was collected using a selfadministrated, paper-and-pencil survey that took approximately 10 minutes to complete. The surveys were drafted in English and translated into Chinese (Cantonese), with the support from professional translators and back-translation into English, in order to assure the accuracy of the survey.

Data collection involved a mall intercept method, which took place in public areas outside Harbour City, a popular shopping centre in Tsim Sha Tsui, Hong Kong, over a 14-week period. There are numerous retailers selling branded electronic appliances and fashion apparel in Harbour City, including notebook computers and sportswear, which were the focal products for this research.

Using a skip-interval approach to enhance the randomness and generalisability of the research, every third shopper coming out of electronic-appliance stores and sportsapparel stores in the shopping mall was approached (Spry et al., 2011), provided with a brief of the research, and asked to volunteer their participation. Those who agreed nominated a focal brand they were familiar with prior to completing the survey by answering questions about their perceptions of their nominated brand.

Hong Kong is an international city with a multi-cultural, highly sophisticated free market economy (Barnes et al., 2009) and with a well-developed retail sector (Liao \& Shi, 2009). Hong Kong consumers are equipped with sufficient knowledge of international brands, and particularly the major brands in the focal product categories, which were also available in major Hong Kong retail outlets.

\section{Measures}

Two product categories featuring leading international brands were selected as product stimuli, namely, laptop-computer brands for the high-involvement product category (for example, Lenovo, Asus, Dell and Sony) and sportswear brands for the low-involvement product category (for example, Nike, Puma, Reebok and Adidas). These categories represent different combinations of marketing factors, such as price, country of origin, number of distribution stores (outlets) and brand reputation.

Drawing multiple-item scales from prior branding and social-media-marketing studies (see Table 1), measures used seven-point Likert scales, ranging from 'strongly disagree' (1) to 'strongly agree' (7). Measurement of the CBBE dimensions included four items for brand awareness, six items for brand associations, five items for perceived quality and five items for brand loyalty adopted from Yoo et al. (2000). FCSM and UGSM operationalisation accounted for consumers' satisfaction with the content generated by the brand and other consumers on social-media platforms, with four items used to measure each type, adopted from Schivinski and Dabrowski 
(2016). Regarding distribution intensity, three items measured consumers' perceptions on the number of stores carrying the focal brand (Yoo \& Donthu, 2002). Lastly, enduring involvement used three items drawn from O'Cass (2000), with age and gender included as controls.

\section{Results}

\section{Respondent profile}

Having invited 515 shoppers to participate in the survey, 242 agreed to participate. After discarding 32 incomplete questionnaires, 210 respondents, who were over 18 years old and social-media users, returned usable questionnaires (105 questionnaires for each involvement group) resulting in a $40.8 \%$ response rate for the sample used for data analysis.

The sample comprised $51 \%$ male ( $49 \%$ female) respondents, with ages ranging from 18 to $66+($ mean $=26-30$ years $)$ and a large proportion aged between 18 and 35 (74.8\%). Most respondents were university educated (58\%), with a further $23 \%$ having completed other forms of tertiary education, and were typically engaged in full-time employment (58\%).

Regarding social-media usage, all respondents had experience in using social media and Facebook. Most respondents (87\%) had a Facebook account for three or more years, and accessed Facebook 6-10 times a day on average, with $40 \%$ of respondents signed into Facebook all of the time.

A manipulation check confirmed that respondents' reported involvement level (the summated mean of the three-item involvement scale) was significantly higher ( $\mathrm{p}<$ .001 ) for notebook computers (4.3 out of 7) than for sportswear (2.7 out of 7). This result justified the classification of notebook computers as a high-involvement product and sportswear as a low-involvement product.

In summary, respondents were typically relatively young, tertiary-educated graduates in full-time employment. They represented the intended population of well-educated Hong Kong consumers able to buy foreign-branded notebook computers and sportswear. Respondents had a strong preference in using Facebook and were experienced Facebook users. Thus, their responses were accepted as representative of social-media users in Hong Kong and suitable for the purpose of this research.

\section{Data Analysis}

The analysis featured partial least squares-structural equation modelling (PLS-SEM) using SmartPLS 3.2.8 (Ringle et al., 2015), using the 5,000-bootstrap procedure. PLSSEM is suitable for studies with smaller sample sizes (e.g. less than 500), which fits the current study (Hair et al., 2017). Additionally, PLS-SEM is also appropriate for studies aimed at explaining the variance of constructs in complex models with 
theoretical knowledge and for identifying the key driver constructs in conceptual models with many reflective measurement items (Hair et al., 2017), as with this study. Furthermore, simulation studies have concluded that PLS-SEM is a suitable SEM technique when compared to CB-SEM (Shmueli et al., 2019), hence it is arguably preferable given the context of this study. Lastly, PLS-SEM has become an increasingly used SEM tool across business disciplines and virtually all social-science disciplines (Hair et al., 2017).

Data analysis featured two stages: (1) the assessment of reliability and validity of the measurement (outer) model and (2) the assessment of the structural (inner) model, examining the path coefficients, p-values and R2 values. To assess the reliability of the latent constructs, the individual item loadings, Cronbach's alpha and composite reliability were evaluated for each construct (Hair et al., 2017). The results confirmed that Cronbach's alpha and composite reliability of each construct exceed 0.90 (See Table 1), indicating a good level of internal consistency in the responses (Nunnally \& Bernstein, 1994). Additionally, the loading of each item was greater than 0.50, which is considered as meaningful (Hair et al., 2017), and all but one item had loadings .80 or greater. All loadings were highly significant $(\mathrm{p}<.001)$. Finally, the Cronbach's alpha and composite reliability of the involvement scale both exceeded 0.85 , indicating a good level of internal consistency.

Table 1: Outer Model Results

\begin{tabular}{|c|c|c|c|c|c|}
\hline Construct & Mean & $S D$ & Loading & Alpha & $\mathbf{C R}$ \\
\hline Firm-created social-media brand communication & & & & .95 & .96 \\
\hline $\begin{array}{l}\text { I am satisfied with the company's social-media communications for } \\
\text { Brand X }\end{array}$ & 3.90 & 1.19 & $.93^{*}$ & & \\
\hline $\begin{array}{l}\text { The level of the company's social-media communications for Brand X } \\
\text { meets my expectations }\end{array}$ & 3.95 & 1.21 & $.94^{*}$ & & \\
\hline $\begin{array}{l}\text { The company's social-media communications for Brand } \mathrm{X} \text { are very } \\
\text { attractive }\end{array}$ & 3.90 & 1.25 & $.93^{*}$ & & \\
\hline $\begin{array}{l}\text { The company's social-media communications for Brand X perform } \\
\text { well, when compared with the social media of other companies }\end{array}$ & 3.84 & 1.20 & $.91 *$ & & \\
\hline User-generated social-media brand communication & & & & .95 & .96 \\
\hline $\begin{array}{l}\text { I am satisfied with the content generated on social-media sites by other } \\
\text { users about Brand X }\end{array}$ & 3.85 & 1.03 & $.93 *$ & & \\
\hline $\begin{array}{l}\text { The level of the content generated on social-media sites by other users } \\
\text { about Brand X meets my expectations }\end{array}$ & 3.85 & 1.08 & $.94^{*}$ & & \\
\hline The content generated by other users about Brand $\mathrm{X}$ is very attractive & 3.80 & 1.09 & $.92 *$ & & \\
\hline $\begin{array}{l}\text { The content generated on social-media sites by other user about Brand } \\
\text { X performs well, when compared with other brands }\end{array}$ & 3.82 & 1.17 & $.93^{*}$ & & \\
\hline Distribution intensity & & & & .90 & .93 \\
\hline $\begin{array}{l}\text { There are more stores that sell Brand } \mathrm{X} \text {, as compared to its competing } \\
\text { brands }\end{array}$ & 4.25 & 1.42 & $.87 *$ & & \\
\hline $\begin{array}{l}\text { The number of the stores that deal with Brand } \mathrm{X} \text { is more than that of its } \\
\text { competing brands }\end{array}$ & 4.25 & 1.44 & $.88^{*}$ & & \\
\hline Brand $\mathrm{X}$ is distributed through as many stores as possible & 4.94 & 1.43 & $.90^{*}$ & & \\
\hline I can buy Brand X everywhere in Hong Kong & 5.26 & 1.45 & $.85^{*}$ & & \\
\hline
\end{tabular}

Note: * all loadings highly significant, $\mathrm{p}<.001, \mathrm{SD}=$ Standard Deviation, $\mathrm{CR}=$ Composite Reliability 
Table 1: Outer Model Results (Continued)

\begin{tabular}{|c|c|c|c|c|c|}
\hline Construct & Mean & SD & Loading & Alpha & $\mathbf{C R}$ \\
\hline Brand awareness & & & & .91 & .93 \\
\hline I can recognise Brand $\mathrm{X}$ among other competing brands & 5.06 & 1.33 & $.90 *$ & & \\
\hline I am aware of Brand X & 4.68 & 1.39 & $.90^{*}$ & & \\
\hline I am familiar with Brand $X$ & 4.73 & 1.36 & $.90^{*}$ & & \\
\hline $\begin{array}{l}\text { Brand X comes to mind when I think of notebook } \\
\text { computers }\end{array}$ & 4.88 & 1.37 & $.84^{*}$ & & \\
\hline Brand association & & & & .91 & .93 \\
\hline $\mathrm{X}$ is a unique brand & 4.46 & 1.41 & $.84 *$ & & \\
\hline $\begin{array}{l}\mathrm{X} \text { has very unique brand image, compared to competing } \\
\text { brands }\end{array}$ & 4.50 & 1.49 & $.86^{*}$ & & \\
\hline I like the brand image of $\mathrm{X}$ & 4.61 & 1.25 & $.86^{*}$ & & \\
\hline Some characteristics of Brand X come to my mind quickly & 4.67 & 1.43 & $.84^{*}$ & & \\
\hline I can quickly recall the symbol or logo of Brand X & 5.41 & 1.39 & $.80 *$ & & \\
\hline I have no difficultly in imaging Brand $\mathrm{X}$ in my mind & 5.42 & 1.29 & $.81^{*}$ & & \\
\hline Perceived quality & & & & .95 & .96 \\
\hline The quality of Brand $\mathrm{X}$ is extremely high & 4.98 & 1.23 & $.94 *$ & & \\
\hline The functions of Brand $\mathrm{X}$ are very high & 4.91 & 1.15 & $.91 *$ & & \\
\hline Brand X offers products of consistent quality & 4.94 & 1.11 & $.92 *$ & & \\
\hline Brand $\mathrm{X}$ offers very reliable products & 5.16 & 1.11 & $.91 *$ & & \\
\hline Brand $\mathrm{X}$ offers products with excellent features & 4.87 & 1.26 & $.88^{*}$ & & \\
\hline Brand loyalty & & & & .92 & .94 \\
\hline I consider myself to be loyal to Brand X & 3.96 & 1.63 & $.90^{*}$ & & \\
\hline Brand $\mathrm{X}$ is always my first choice & 3.97 & 1.66 & $.91 *$ & & \\
\hline $\begin{array}{l}\text { I will not buy other brands if Brand } \mathrm{X} \text { is unavailable at the } \\
\text { store }\end{array}$ & 3.06 & 1.58 & $.79 *$ & & \\
\hline $\begin{array}{l}\text { I am willing to buy Brand } X \text { even if its price is a little } \\
\text { higher than that of its competitors }\end{array}$ & 3.70 & 1.65 & $.92 *$ & & \\
\hline I intend to remain a customer of Brand X & 4.20 & 1.61 & $.85^{*}$ & & \\
\hline
\end{tabular}

Note: * all loadings highly significant, $\mathrm{p}<.001, \mathrm{SD}=$ Standard Deviation, $\mathrm{CR}=$ Composite Reliability

Reported in Table 2, the average variance extracted (AVE) scores for all constructs in the model exceeded the recommended .50 threshold, satisfying the AVE criterion for convergent validity (Hair et al., 2017). Using the Fornell-Larcker (1981) criterion to assess discriminant validity, the square roots of the AVEs for the latent constructs were larger than the corresponding latent-variable correlations as required.

Table 2: Construct Correlation Matrix and AVE

\begin{tabular}{|c|c|c|c|c|c|c|c|c|c|c|c|c|c|c|}
\hline & & Mean & SD & V1 & $\mathbf{V 2}$ & V3 & V4 & V5 & V6 & V7 & V8 & V9 & AVE & $\begin{array}{l}\text { Square } \\
\text { root of } \\
\text { AVE }\end{array}$ \\
\hline 1. & $\begin{array}{l}\text { Firm-created social-media } \\
\text { brand communication }\end{array}$ & 3.9 & 1.13 & 1 & & & & & & & & & .86 & .93 \\
\hline 2. & $\begin{array}{l}\text { User-generated social-media } \\
\text { brand communication }\end{array}$ & 3.83 & 1.02 & $.78^{* *}$ & 1 & & & & & & & & .87 & .93 \\
\hline 3. & Distribution intensity & 4.67 & 1.26 & $.42^{* *}$ & $.45^{* *}$ & 1 & & & & & & & .76 & .87 \\
\hline 4. & Brand awareness & 4.84 & 1.21 & $.49^{* *}$ & $.47^{* *}$ & $.61^{* *}$ & 1 & & & & & & .78 & .88 \\
\hline 5. & Brand association & 4.85 & 1.15 & $.47^{* *}$ & $.43^{* *}$ & $.49^{* * *}$ & $.78^{* *}$ & 1 & & & & & .70 & .83 \\
\hline 6. & Perceived quality & 4.97 & 1.07 & $.53^{* *}$ & $.47^{* *}$ & $.46^{* *}$ & $.70^{* *}$ & $.76^{* *}$ & 1 & & & & .83 & .91 \\
\hline 7. & Brand loyalty & 3.78 & 1.43 & $.52^{* *}$ & $.48^{* * *}$ & $.33^{* * *}$ & $.63^{* *}$ & $.68^{* *}$ & $.68^{* * *}$ & 1 & & & .77 & .88 \\
\hline 8. & Age & 3.58 & 2.02 & $\begin{array}{c}- \\
.19^{* * *}\end{array}$ & $-.15^{*}$ &.- & -.09 & -.09 & $\begin{array}{c}- \\
.18^{* * *}\end{array}$ & .08 & 1 & & - & - \\
\hline
\end{tabular}




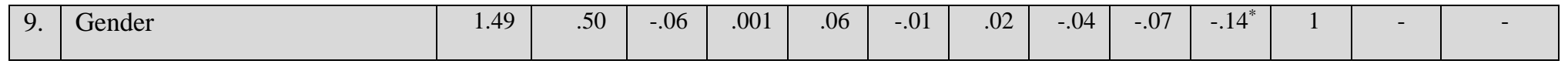

Note: correlations significant at $* * \mathrm{p}<.01, * \mathrm{p}<.05$

\section{Inner (Structural) Model Results}

The hypotheses for the relationships posited in the conceptual model were examined by using the inner (structural) model results. The hypotheses were tested by examining the $t$-values, standardised coefficient beta values and coefficient of determination $\left(R^{2}\right.$ value). A hypothesis was accepted when the $t$-value was larger than critical value (i.e. $t \geq 1.96, p \leq .05$ ) and being marginally significant when $t \geq 1.67, p$ $\leq .10$, using a two-tailed test. In order to test the significance of both the measurement and structural models, the 5,000-bootstrap procedure was used (Hair et al., 2017).

As presented in Figure 2 and Table 3, the results support seven of the twelve hypotheses. Specifically, the impact of FCSM on brand loyalty was the strongest ( $\beta$ $=.391, p=.000)$, followed by perceived quality $(\beta=.363, p=.000)$, brand association $(\beta=.285, p=.003)$ and brand awareness $(\beta=.227, p=.006)$. Thus, H1a$1 \mathrm{~d}$ were supported.

In contrast, UGSM had a weak, non-significant, positive influence on brand awareness $(\beta=.080, p=.369)$, brand association $(\beta=.057 p=.582)$, perceived quality $(\beta=.054, p=.562)$ and brand loyalty $(\beta=.133, p=.215)$. Thus, H2a-2d were not supported.

Furthermore, the influence of distribution intensity on brand awareness was the strongest $(\beta=.489, p=.000)$, followed by brand association $(\beta=.357, p=.000)$ and perceived quality $(\beta=.277, p=.001)$, whilst the impact of distribution intensity on brand loyalty was marginally significant $(\beta=.149, p=.062)$. Thus, H3a-c was supported and H3d was marginally supported. Age and gender had no meaningful influence on the model.

The $R^{2}$ values were used to evaluate the explanatory power of the conceptual model (see Figure 2). The $R^{2}$ values were as follows for brand awareness (.44), brand associations (.33), perceived quality (.36) and brand loyalty (.33). This exceeds the recommended criterion benchmark of $R^{2}$ values in the model being greater than .10 (Chin, 1998), with a value of .20 considered high for consumer-behaviour studies (Vock et al., 2013). 
Figure 2: Conceptual Model Results

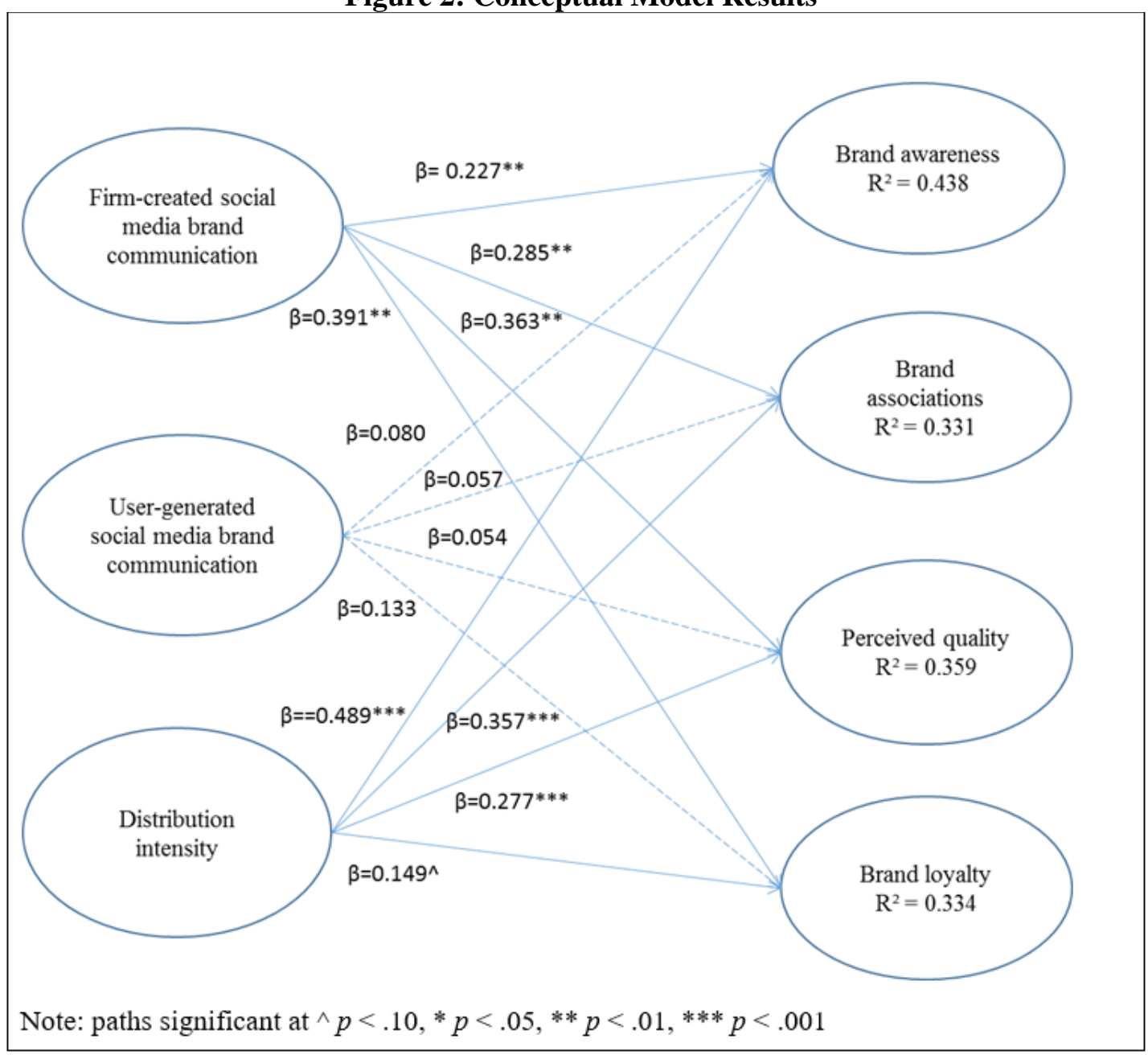

To assess the moderating effects of product involvement level (H4a-4c, H5a-5c, H6a$6 c)$, the data was split into equally sized high- and low-involvement groups ( $\mathrm{n}=105$ each), and multiple group analysis (MGA) was then run in SmartPLS using the permutation technique, with the 5,000-permutation (one-tailed-test) procedure used (Hair et al., 2017). Table 4 presents the results of the permutation MGA analysis, along with the inner-model results for each involvement subgroup. Specifically, the influence of FCSM on the four CBBE dimensions was notably stronger for the highinvolvement group. A significant difference across the two groups was found in the influence of FCSM on brand awareness $(p=.022)$, brand association $(p=.003)$, perceived quality $(\mathrm{p}=.011)$ and brand loyalty $(\mathrm{p}=.011)$. Thus, H4a $-\mathrm{H} 4 \mathrm{~d}$ were supported.

In relation to the moderated influence of UGSM on the four CBBE dimensions varied across the two involvement groups the findings were: a marginally significant difference for the influence of UGSM on brand awareness $(p=.089)$; a significant difference for brand association ( $\mathrm{p}=.048)$; a marginally significant difference for brand loyalty $(\mathrm{p}=.089)$; and a non-significant $(\mathrm{p}>.10)$ difference for perceived quality $(\mathrm{p}=.204)$. Thus, H5b was supported and H5a and H5c were marginally supported, but H5d was not supported. Furthermore, a marginally significant difference was found for the influence of distribution intensity on brand awareness ( $p$ 
$=.061)$, but non-significant differences across the two involvement groups were found for the influence of distribution intensity on brand associations $(\mathrm{p}=.168)$, perceived quality $(\mathrm{p}=.1454)$ and brand loyalty $(\mathrm{p}=.232)$. Thus, H6a was partially supported and H6b - H6d were not supported.

Table 3: PLS-SEM Results

\begin{tabular}{|c|c|c|c|}
\hline Relationship & Path Coefficient & $t$-value & $p$-value \\
\hline \multicolumn{4}{|l|}{ FCSM $\rightarrow$ CBBE dimensions } \\
\hline FCSM $\rightarrow$ Brand awareness & .227 & 2.76 & .006 \\
\hline FCSM $\rightarrow$ Brand association & .285 & 3.00 & .003 \\
\hline FCSM $\rightarrow$ Perceived quality & .363 & 4.48 & .000 \\
\hline FCSM $\rightarrow$ Brand loyalty & 391 & 4.12 & .000 \\
\hline \multicolumn{4}{|l|}{ UGSM $\rightarrow$ CBBE dimensions } \\
\hline UGSM $\rightarrow$ Brand awareness & .080 & 0.90 & .369 \\
\hline UGSM $\rightarrow$ Brand association & .057 & 0.55 & .582 \\
\hline UGSM $\rightarrow$ Perceived quality & .054 & 0.58 & .562 \\
\hline UGSM $\rightarrow$ Brand loyalty & .133 & 1.24 & .215 \\
\hline \multicolumn{4}{|l|}{ Distribution intensity $\rightarrow$ CBBE dimensions } \\
\hline Distribution intensity $\rightarrow$ Brand awareness & .489 & 8.21 & .000 \\
\hline Distribution intensity $\rightarrow$ Brand association & .357 & 4.59 & .000 \\
\hline Distribution intensity $\rightarrow$ Perceived quality & 277 & 3.49 & .001 \\
\hline Distribution intensity $\rightarrow$ Brand loyalty & .149 & 1.88 & .062 \\
\hline \multicolumn{4}{|l|}{ Control variables } \\
\hline Age $\rightarrow$ Brand awareness & .067 & 1.16 & 247 \\
\hline Age $\rightarrow$ Brand association & .049 & 0.77 & .442 \\
\hline Age $\rightarrow$ Perceived quality & -.052 & 0.86 & .391 \\
\hline Age $\rightarrow$ Brand loyalty & .198 & 3.41 & .001 \\
\hline Gender $\rightarrow$ Brand awareness & -.017 & 0.31 & .757 \\
\hline Gender $\rightarrow$ Brand association & .027 & 0.45 & 653 \\
\hline Gender $\rightarrow$ Perceived quality & -.047 & 0.80 & .425 \\
\hline Gender $\rightarrow$ Brand loyalty & -.024 & 0.41 & .682 \\
\hline
\end{tabular}

Table 4: Results of Multiple Group Analysis

\begin{tabular}{|c|c|c|c|c|}
\hline \multirow[t]{2}{*}{ Item/ Construct } & \multicolumn{2}{|c|}{ Path Coefficient } & \multicolumn{2}{|c|}{ Difference } \\
\hline & $\begin{array}{c}\text { High } \\
\text { Involvement }\end{array}$ & $\begin{array}{c}\text { Low } \\
\text { Involvement }\end{array}$ & $\begin{array}{c}\text { Mean Difference } \\
\text { (absolute value) }\end{array}$ & $p$-value \\
\hline \multicolumn{5}{|l|}{ FCSM $\rightarrow$ CBBE dimensions } \\
\hline FCSM $\rightarrow$ Brand awareness & $.395 * * *$ & .061 & $.334 *$ & .022 \\
\hline FCSM $\rightarrow$ Brand association & $.574 * * *$ & .033 & $.541 * *$ & .003 \\
\hline FCSM $\rightarrow$ Perceived quality & $.560 * * *$ & .200 & $.360 *$ & .011 \\
\hline FCSM $\rightarrow$ Brand loyalty & $.611 * * *$ & .171 & $.440 *$ & .011 \\
\hline \multicolumn{5}{|l|}{ UGSM $\rightarrow$ CBBE dimensions } \\
\hline UGSM $\rightarrow$ Brand awareness & -.016 & $.223^{\wedge}$ & $.239^{\wedge}$ & .089 \\
\hline UGSM $\rightarrow$ Brand association & -.115 & .229 & $.344 *$ & .048 \\
\hline UGSM $\rightarrow$ Perceived quality & -.018 & .138 & .156 & .196 \\
\hline UGSM $\rightarrow$ Brand loyalty & .014 & $.293^{*}$ & $.279^{\wedge}$ & .089 \\
\hline \multicolumn{5}{|l|}{ Distribution intensity $\rightarrow$ CBBE dimensions } \\
\hline Distribution intensity $\rightarrow$ Brand awareness & $.373 * * *$ & $.562 * * *$ & $.189^{\wedge}$ & .061 \\
\hline Distribution intensity $\rightarrow$ Brand association & $.266^{*}$ & $.422 * * *$ & .156 & .168 \\
\hline Distribution intensity $\rightarrow$ Perceived quality & .162 & $.338^{* *}$ & .176 & .154 \\
\hline Distribution intensity $\rightarrow$ Brand loyalty & .084 & .204 & .120 & .232 \\
\hline Control variables & & & & \\
\hline
\end{tabular}




\begin{tabular}{|l|c|c|c|c|}
\hline Age $\rightarrow$ Brand awareness & .035 & .066 & -.031 & .261 \\
\hline Age $\rightarrow$ Brand association & .072 & .112 & -.040 & .478 \\
\hline Age $\rightarrow$ Perceived quality & -.050 & -.030 & -.020 & .436 \\
\hline Age $\rightarrow$ Brand loyalty & $.201 * * *$ & $.219 * * *$ & -.018 & .463 \\
\hline Gender $\rightarrow$ Brand awareness & -.038 & -.045 & .007 & .472 \\
\hline Gender $\rightarrow$ Brand association & -.039 & .040 & -.079 & .251 \\
\hline Gender $\rightarrow$ Perceived quality & -.127 & -.013 & -.115 & .158 \\
\hline Gender $\rightarrow$ Brand loyalty & -.104 & .012 & -.116 & .162 \\
\hline \multicolumn{2}{|r}{ Notes: significant at ${ }^{\wedge} \mathrm{p}<.10, * \mathrm{p}<.05, * * \mathrm{p}<.01, * * * \mathrm{p}<.001$} \\
\end{tabular}

\section{Theoretical Implications}

Branding research posits that social media communication and distribution channel intensity are useful drivers of CBBE (Nguyen et al., 2011; Schivinski \& Dabrowski, 2015). In contrast, the integration of both social media communication and distribution intensity on CBBE for both high- and low-involvement products has not been subject to examination. The present study contributes to the literature in this area by examining the impact of both social media brand communication and distribution intensity on $\mathrm{CBBE}$ for both high- and low-involvement products.

The main conclusion from the findings of this study is that the positive information provided by FCSM and by distribution intensity, has an important influence on CBBE. Specifically, considering the combined samples, the effects of FCSM on all four CBBE dimensions are positive and significant, matching the effects of distribution intensity on brand awareness, brand associations and perceived quality. In addition, the results of this analysis also show that the influence of FCSM on the dimensions of perceived quality and brand loyalty is stronger than that arising when distribution intensity is considered. The effects of distribution intensity on brand awareness and brand associations are higher than in the case of FCSM. Therefore, given the importance of brand loyalty in the CBBE-creation process, the conclusion is that FCSM is an important driver of CBBE as a whole, whilst distribution intensity is only effective in building brand awareness, brand associations and perceived quality.

The results also support the importance of both social media communication and distribution channel intensity in communicating brand-related information to build strong and favourable brand knowledge in consumers' minds, thus strengthening consumers' purchase intention (Cheung et al., 2019b). Ultimately, the research results support the arguments related to the value of both social media communication and distribution channel intensity as espoused in the recent literature (e.g. Bell et al., 2017; Herhausen et al., 2015; Sun et al., 2015).

The findings of this study also offer insights related to the relationship between UGSM and the CBBE dimensions. Inconsistent with previous studies' findings (Schivinski \& Dabrowski, 2016), a positive non-significant relationship between UGSM and CBBE dimensions was found for the combined sample. Difference in the results can ensue by an overload of UGSM available on social-networking sites, perceived as having increased dramatically in Hong Kong. 
Based on the theory of information overload introduced by Schneider (1987), Park \& Lee (2009) found that the overload of positive UGSM availability creates uncertainty, ambiguity and complexity for the available information. Such overloading of information also reduces consumers' perception of the usefulness of the available UGSM, such that these communication effects are not as useful in stimulating consumers' purchase intention. Additionally, Bright et al. (2015) used Lang's (2000) limited-capacity model to argue along similar lines, further demonstrating that UGSM may not be a strong determinant in building CBBE in a society with considerable UGSM activity, such as Hong Kong.

On reflection, the findings of the present study support the argument that, in the web 2.0 era, there is plenty of UGSM available on the various social media platforms, causing an abundance of UGSM available via social media for consumers. Hence, consumers may feel overwhelmed by the large quantity of UGSM, becoming unwilling to spend enough cognitive resources to process such a high volume of UGSM (Bright et al., 2015). In addition, users rewarded for their recommendations sometimes generate UGSM, and the credibility of the information provided is questioned (Pongjit and Beise-Zee, 2015). The implication here is that abundance of UGSM written by users who received rewards may reduce UGSM credibility and create information overload, also reducing its usefulness in building CBBE dimensions.

This research also contributes to knowledge related to the moderating effect of the level of product involvement on the impact of FCSM, UGSM and distribution intensity on CBBE dimensions, partially confirming the moderating effects of product involvement level. The results indicate that product-involvement level has a significant moderating effect on the relationship between FCSM and all CBBE dimensions, stronger for high-involvement products than for low-involvement products. However, a consistent moderating effect does not apply to the impact of UGSM and distribution intensity on the CBBE dimensions. The implication is that the results only partially support the findings of previous studies in this area. Consistent with the findings of Radder and Huang (2008), the suggestion is that the consumers in this study were more willing to notice and accept advertising messages for highinvolvement products than for low-involvement products, and thus being more willing to pay attention to relevant firm-initiated information about high-involvement products in a social media context (Cheung et al., 2019a).

Inconsistent with the literature (Radder \& Huang, 2008), the findings indicate that the effects of UGSM on brand awareness, brand associations and perceived quality were negative and non-significant for high-involvement products. As discussed above, the explanation may relate to the characteristics of UGSM communications, which may be generated by users who received rewards for recommendations drawing information credibility into question, with a potential negative effect on other consumers' attitudes toward the associated brands (Pongjit \& Beise-Zee, 2015). Consumers may feel overwhelmed by too much UGSM content for high-involvement products being available on the Internet, result of information overload (Cheung \& Thadani, 2012). 
Consistent with the argument that the quantity of user-generated content affects consumer purchase intentions for low-involvement products (Park et al., 2007), the effects of UGSM on brand awareness and perceived quality were positive and marginally significant for low-involvement products. The conclusion is that productinvolvement level has a significant moderating effect on the relationship between UGSM and brand awareness, whilst the moderating effect is marginally significant for the relationship between UGSM and brand associations. This result may be explained by consumers' information-search behaviour for low-involvement products. As consumers have a relatively lower level of motivation to process user-generated content, the quantity of positive, user-generated content may help them obtain information about the popularity of low-involvement products (Park et al., 2007). Thus, even though there may be information overload in a social-media context, positive UGSM can still strengthen brand awareness and brand association for lowinvolvement products.

The non-significant moderating effect of product involvement on the relationship between distribution intensity and the CBBE dimensions found in this study may result from consumers' attitude towards high- and low-involvement products. If consumers who are willing to search for product information for high-involvement products are well-informed from the outset, then they may have formed a prepurchase opinion, such that it becomes important for them to be able to easily find their desired products (Swoboda et al., 2009). Therefore, intensive distribution may assist in building positive consumer perceptions for branded high-involvement products.

For low-involvement products, consumers are likely to build brand perceptions based on affection, following the 'beliefs-behaviour-affect' hierarchy (Olshavsky \& Granbois, 1979). In other words, they lack the motivation to search for and evaluate brand information in their decision-making process, and hence, shelf visibility may facilitate purchase intention, thus justifying the importance of intensive distribution as an important element contributing to CBBE for low-involvement products (Huang \& Sarigöllü, 2012).

Finally, similar with consumers in other developed countries, the sample of Hong Kong consumers participating in this study arguably value convenience and enjoy shopping, thus being more receptive to information from distribution channels. Hence, for this sample, distribution intensity improves consumers' ability to recall and recognise brands (Yoo et al., 2000).

\section{Managerial Implications}

This study calls on marketers to consider the integration of social media communication and distribution intensity as marketing tools in brand building, shows that intensive distribution can contribute to the formation of $\mathrm{CBBE}$ regardless of product-involvement level. Thus, a brand being available to consumers in more stores than competing brands may benefit from consumers' improved brand knowledge and stronger CBBE. 
Since FCSM is an effective tool in building CBBE for high-involvement products, marketers should prepare quality brand pages, and making frequent updates available on social-networking sites to fulfil consumers' information acquisition about their products and brands (Cheung et al., 2020a). Additionally, marketers may also consider including vivid, novel, consistent and entertaining messages that incorporate storytelling and consistently communicate the brand name, logo, slogan, aesthetic features and value propositions on their brand pages (Mangold \& Faulds, 2009). Activities such as these can be effective in creating hedonic value for the brand, strengthening brand loyalty (Cheung et al., 2020b).

Finally, this study found that FCGM and intensive distribution are significant factors in generalising the CBBE-formation process, suggesting that physical channels complement social-media marketing tools. Thus, brands are recommended to integrate features in their offline stores into their social-media platforms, providing information about physical-store assortment availability in their social-media platforms to attract consumers to visit the physical stores to taste and experience features of products (Herhausen et al., 2015).

\section{Limitations and Future Research Directions}

The research enhances understanding of how to use social-media brand communication and distribution strategy to strengthen consumer-based brand equity for both high- and low-involvement products, such as laptop computers and sportswear. Examining only one product type (namely a notebook computer and/or sportswear) for each involvement level, limits the generalisability of the findings to other product categories. Future research may improve the generalisation of the findings by replicating the present study for other product categories and types of products within each category.

Additionally, the respondents in this study, who came out from electronic-appliance stores and sports-apparel stores, may have a higher CBBE of the focal products than those who walk out from restaurants, supermarkets and fashion stores, etc. Such possibility of bias can be addressed by recruiting respondents from various stores in the future research.

A further limitation arises because this study relies on surveys to test the proposed model. Future research may consider using experiments to test consumer perceptions of FCSM and UGSM, exploring the in-depth understanding of the links between social media communication and CBBE dimensions. Further, the present study examined the impact of positive UGSM on CBBE dimensions only, omitting the impact of negative UGSM. Thus, future research may include negative UGSM to enhance the comprehensiveness of the model.

Finally, the study design is cross-sectional in nature and focus is limited to laptop computers and sportswear in one location, Hong Kong. Given the rapid change of consumer values in this area, confirming the findings on other locations with diverse cultures, along with the adoption of a longitudinal research design is recommended for future research, including comparisons between countries with diverse cultures as 
well as other industries, such as the service sector, to enhance the generalizability of the findings.

\section{Implications for Asian Business Context}

Consumer-based brand equity (CBBE) has merited substantive research effort because it plays a considerable role in driving positive business outcomes. Given the growing importance of social-media brand communication, brands are suggested to allocate more resources in social media marketing activities and to reduce resources in distribution by closing retail stores. Nevertheless, such practices may not be appropriate for brand building in Hong Kong, a special region of China with a highly assessable urban environment, characterized by plenty of retail stores and shops selling products of globalized brands.

Consumers in Hong Kong enjoy shopping in their decision-making process, seeking to obtain experiences about products in stores so as to reduce the perceived risk in their buying process, thus justifying brands to distribute their products intensively in order to build CBBE even though the rental cost in Hong Kong is high. Although the importance of distribution channels and social-media brand communication on brand building is recognized, the understanding about their relative importance in brand building of various product categories is limited. With such limited knowledge, brand managers in Hong Kong are facing dilemmas in allocating marketing budgets in social media or distribute products intensively.

Seeking to address the aforementioned managerial problems, this study examines the importance of social media brand communication and distribution intensity for both high and low involvement products in Hong Kong. The findings of this study suggest that in order to build CBBE, brands need to allocate their resources in preparing firminitiated social media brand communication and distribute their products intensively. In conclusion, although marketers in Hong Kong face the problem of high rental costs, they are advised to spend substantial resources to distribute their products intensively in order to build CBBE, and thereby enjoying business success in Hong Kong.

\section{References}

Aaker, D. A., (1991), Managing brand equity, Free Press, New York.

Aaker, D. A., (2001), Strategic market management, Wiley, New York.

Ataman, M. B., Mela, C. F., \& Van Heerde, H. J., (2008), "Building brands", Marketing Science, vol. 27, no. 6, pp. 1036-1054.

Ataman, M. B., Van Heerde, H. J., \& Mela, C. F., (2010), “The long-term effect of marketing strategy on brand sales", Journal of Marketing Research, vol. 47, no. 5, pp. 866-882.

Barnes, B. R., Siu, N. Y., Yu, Q., \& Chan, S. S., (2009), "Exploring cosmetics advertising in southern China: An investigation of Hong Kong and Shenzhen", International Journal of Advertising, vol. 28, no. 2, pp. 369-393.

Bell, D. R., Gallino, S., \& Moreno, A., (2017), "Offline showrooms in omnichannel retail: Demand and operational benefits", Management Science, vol. 64, no. 4, pp. 1629-1651. 
Bright, L. F., Kleiser, S. B., \& Grau, S. L., (2015), "Too much Facebook? An exploratory examination of social media fatigue", Computers in Human Behaviour, vol. 44, no. March, pp. 148-155.

Bruhn, M., Schoenmueller, V., \& Schäfer, D. B., (2012), "Are social media replacing traditional media in terms of brand equity creation?", Management Research Review, vol. 35 , no. 9 , pp. $770-790$.

Cao, L., \& Li, L., (2015), "The impact of cross-channel integration on retailers' sales growth", Journal of Retailing, vol. 91, no. 2, pp. 198-216.

Cheung, C. M., \& Thadani, D. R., (2012), "The impact of electronic word-of-mouth communication: A literature analysis and integrative model", Decision Support Systems, vol. 54, no. 1, pp. 461-470.

Cheung, M. L., Guilherme D. P., Philip J. R. III., \& Mauro de O., (2019), Issues in consumerbased brand equity and agenda for future research, In The changing landscape of international business (Ed.), Cambridge Scholars Publishing, United Kingdom.

Cheung, C. L., Pires, G., \& Rosenberger, P. J., (2020a), "The influence of perceived social media marketing elements on consumer-brand engagement and brand knowledge", Asia Pacific Journal of Marketing and Logistics, vol. 32, no. 3, pp. 695-720.

Cheung, C. L., Pires, G., Rosenberger, P. J., \& De Oliverira, M. J., (2020b), "Driving consumer-brand engagement and co-creation by brand interactivity", Marketing Intelligence \& Planning, vol. ahead-of-print, no. ahead-of-print.

Chin, W. (1998)., The partial least squares approach for structural equation modelling, In Modern methods for business research, Laurence Erlbaum Associates, New Jersey.

Christodoulides, G., De Chernatony, L., Furrer, O., Shiu, E., \& Abimbola, T., (2006), "Conceptualising and measuring the equity of online brands", Journal of Marketing Management, vol. 22, no. 7-8, pp. 799-825.

Coulter, R., Price, L., \& Feick, L., (2003), "Rethinking the origins of involvement and brand commitment: Insights from post-socialist central Europe", Journal of Consumer Research, vol. 30, no. 2, pp. 151-169.

Davcik, N. S., Vinhas da Silva, R., \& Hair, J. F., (2015), "Towards a unified theory of brand equity: Conceptualizations, taxonomy and avenues for future research", Journal of Product \& Brand Management, vol. 24, no. 1, pp. 3-17.

Fornell, C., \& Larcker, D., (1981), "Evaluating structural equation models with unobservable variables and measurement error", Journal of Marketing Research, vol. 18, no. 1, pp. 39-50.

Godey, B., Manthiou, A., Pederzoli, D., Rokka, J., Aiello, G., Donvito, R., \& Singh, R., (2016), "Social media marketing efforts of luxury brands: Influence on brand equity and consumer behaviour", Journal of Business Research, vol. 69, no. 12, pp. 58335841.

Hair Jr, J. F., Hult, G. T. M., Ringle, C., \& Sarstedt, M., (2017), A primer on partial least squares structural equation modelling (PLS-SEM), Sage Publications, Thousand Oaks.

Herhausen, D., Binder, J., Schoegel, M., \& Herrmann, A., (2015), "Integrating bricks with clicks: Retailer-level and channel-level outcomes of online-offline channel integration", Journal of Retailing, vol. 91, no. 2, pp. 309-325.

Huang, R., \& Sarigöllü, E., (2012), "How brand awareness relates to market outcome, brand equity, and the marketing mix", Journal of Business Research, vol. 65, no. 1, pp. 92-99.

Keller, K., (1993), "Conceptualizing, measuring, and managing customer-based brand equity", Journal of Marketing, vol. 57, no. 1, pp. 1-22.

Keller, K. L., (2009), "Building strong brands in a modern marketing communications environment", Journal of Marketing Communications, vol. 15, no. 2-3, pp. 139-155.

Keller, K. L., (2012), "Understanding the richness of brand relationships: Research dialogue on brands as intentional agents", Journal of Consumer Psychology, vol. 22, no. 2, pp. 186-190.

Keller, K. L., (2013), Strategic brand management: Building, measuring, and managing brand equity, Prentice Hall, London. 
Keller, K. L., (2016), "Reflections on customer-based brand equity: Perspectives, progress, and priorities", AMS Review, vol. 6, no. 1-2, pp. 1-16.

Kim, A. J., \& Ko, E., (2012), "Do social media marketing activities enhance customer equity? An empirical study of luxury fashion brand", Journal of Business Research, vol. 65, no. 10, pp. 1480-1486.

Kumar, A., Bezawada, R., Rishika, R., Janakiraman, R., \& Kannan, P. K., (2016), "From social to sale: The effects of firm-generated content in social media on customer behaviour", Journal of Marketing, vol. 80, no. 1, pp. 7-25.

Kumar, V., Choi, J. B., \& Greene, M., (2017), "Synergistic effects of social media and traditional marketing on brand sales: Capturing the time-varying effects", Journal of the Academy of Marketing Science, vol. 45, no. 2, pp. 268-288.

Lang, A., (2000), "The limited capacity model of mediated message processing", Journal of Communication, vol. 50, no. 1, pp. 46-70.

Liao, Z., \& Shi, X., (2009), "Consumer perceptions of internet-based e-retailing: An empirical research in Hong Kong", Journal of Services Marketing, vol. 23, no. 1, pp. 24-30.

Lin, M. Y., \& Chang, L. H., (2003), "Determinants of habitual behaviour for national and leading brands in China", Journal of Product \& Brand Management, vol. 12, no. 2, pp. 94-107.

Liu, X., Shin, H., \& Burns, A. C., (2019), "Examining the impact of luxury brand's social media marketing on customer engagement: Using big data analytics and natural language processing", Journal of Business Research, In-Press.

Malthouse, E. C., Calder, B. J., Kim, S. J., \& Vandenbosch, M., (2016), "Evidence that usergenerated content that produces engagement increases purchase behaviours", Journal of Marketing Management, vol. 32, no. 5-6, pp. 427-444.

Mangold, W. G., \& Faulds, D. J., (2009), "Social media: The new hybrid element of the promotion mix", Business Horizons, vol. 52, no. 4, pp. 357-365.

Moradi, H., \& Zarei, A., (2012), "Creating consumer-based brand equity for young Iranian consumers via country of origin sub-components effects", Asia Pacific Journal of Marketing and Logistics, vol. 24, no. 3, pp. 394-413.

Morra, M. C., Ceruti, F., Chierici, R., \& Di Gregorio, A., (2017), "Social vs traditional media communication: Brand origin associations strike a chord", Journal of Research in Interactive Marketing, vol. 12, no. 1, pp. 2-21.

MSI, (2018), 2018- 2020 research priorities, Marketing Science Institute, Boston.

Nguyen, T. D., Barrett, N. J., \& Miller, K. E., (2011), "Brand loyalty in emerging markets", Marketing Intelligence \& Planning, vol. 29, no. 3, pp. 222-232.

Nunnally, J., (1978), Psychometric theory, McGraw Hill, New York.

Nunnally, J. C., \& Bernstein, I. H., (1994), Psychological theory, McGraw-Hill, New York.

O'Cass, A., (2000), "An assessment of consumers' product, purchase decision, advertising and consumption involvement in fashion clothing", Journal of Economic Psychology, vol. 21, no. 5, pp. 545-576.

Oliver, R., (1999), “Whence consumer loyalty?”, Journal of Marketing, vol. 63, no. 1, pp. 3344.

Olshavsky, R. W., \& Granbois, D. H., (1979), “Consumer decision making-fact or fiction?”, Journal of Consumer Research, vol. 6, no. 2, pp. 93-100.

Park, D. H., \& Lee, J., (2009), "eWOM overload and its effect on consumer behavioural intention depending on consumer involvement", Electronic Commerce Research and Applications, vol. 7, no. 4, pp. 386-398.

Park, D. H., Lee, J., \& Han, I., (2007), "The effect of on-line consumer reviews on consumer purchasing intention: The moderating role of involvement", International Journal of Electronic Commerce, vol. 11, no. 4, pp. 125-148.

Pauwels, K., \& Neslin, S. A., (2015), "Building with bricks and mortar: The revenue impact of opening physical stores in a multichannel environment", Journal of Retailing, vol. 91, no. 2, pp. 182-197. 
Pongjit, C., \& Beise-Zee, R., (2015), "The effects of word-of-mouth incentivization on consumer brand attitude", Journal of Product \& Brand Management, vol. 24, no. 7, pp. 720-735.

Radder, L., \& Huang, W., (2008), "High-involvement and low-involvement products: A comparison of brand awareness among students at a South African university", Journal of Fashion Marketing and Management: An International Journal, vol. 12, no. 2, pp. 232-243.

Ringle C. M., Wende S., \& Will A., (2005), SmartPLS 2.0, Retrieved from http://www.s martpls.de.

Schivinski, B., \& Dabrowski, D., (2015), "The impact of brand communication on brand equity through Facebook", Journal of Research in Interactive Marketing, vol. 9, no. 1, pp. 31-53.

Schivinski, B., \& Dabrowski, D., (2016), "The effect of social media communication on consumer perceptions of brands", Journal of Marketing Communications, vol. 22, no. 2, pp. 189-214.

Schneider, S. C., (1987), "Information overload: Causes and consequences", Human Systems Management, vol. 7, no. 2, pp. 143-153.

Seo, E. J., \& Park, J. W., (2018), "A study on the effects of social media marketing activities on brand equity and customer response in the airline industry", Journal of Air Transport Management, vol. 66, no. 1, pp. 36-41.

Shmueli, G., Sarstedt, M., Hair, J. F., Cheah, J. H., Ting, H., Vaithilingam, S., \& Ringle, C. M., (2019), "Predictive model assessment in PLS-SEM: Guidelines for using PLSPredict", European Journal of Marketing, vol. 53, no. 11, pp. 2322-2347.

Spry, A., Pappu, R., \& Bettina C. T., (2011), "Celebrity endorsement, brand credibility and brand equity", European Journal of Marketing, vol. 45, no. 6, pp. 882-909.

Srinivasan, S., Rutz, O. J., \& Pauwels, K., (2016), "Paths to and off purchase: Quantifying the impact of traditional marketing and online consumer activity", Journal of the Academy of Marketing Science, vol. 44, no. 4, pp. 440-453.

Sun, S., Cegielski, C. G., \& Li, Z., (2015), "Amassing and analysing customer data in the age of big data: A case study of Haier's Online-to-Offline (O2O) business model", Journal of Information Technology Case and Application Research, vol. 17, no. 3-4, pp. 156165 .

Swoboda, B., Haelsig, F., Schramm-Klein, H., \& Morschett, D., (2009), "Moderating role of involvement in building a retail brand", International Journal of Retail \& Distribution Management, vol. 37, no. 11, pp. 952-974.

Valos, M. J., Maplestone, V. L., Polonsky, M. J., \& Ewing, M., (2017), "Integrating social media within an integrated marketing communication decision-making framework", Journal of Marketing Management, vol. 33, no. 17-18, pp. 1522-1558.

Vock, M., Dolen, W. V., \& Ruyter, K. D., (2013), "Understanding willingness to pay for social network sites", Journal of Service Research, vol. 16, no. 3, pp. 311-325.

Yoo, B., \& Donthu, N., (2002), "Testing cross-cultural invariance of the brand equity creation process", Journal of Product \& Brand Management, vol. 11, no. 6, pp. 380-398.

Yoo, B., Donthu, N., \& Lee, S., (2000), "An examination of selected marketing mix elements and brand equity", Journal of the Academy of Marketing Science, vol. 28, no. 2, pp. 195-211.

Yrjölä, M., Spence, M. T., \& Saarijärvi, H., (2018), "Omni-channel retailing: Propositions, examples and solutions", International Review of Retail, Distribution and Consumer Research, vol. 28, no. 3, pp. 259-276.

Zaichkowsky, J. L., (1986), "Conceptualizing involvement”, Journal of Advertising, vol. 15, no. 2, pp. 4-34. 